\title{
THE IMPACT OF TRANSPORTATION COSTS ON ECONOMIC PERFORMANCES IN CROP PRODUCTION
}

\author{
Bojan Savić ${ }^{1}$, Mladen Petrović ${ }^{2}$, Zorica Vasiljevic ${ }^{3}$ \\ *Corresponding authorE-mail: bsavic@agrif.bg.ac.rs
}

\begin{abstract}
A R T I C LE IN F O
A B S T R A C T

Original Article

Transport activity has significant implications for the other

Received: 06 April 2020

Accepted: 25 July 2020

sectors' activities, including agriculture and agribusiness. Transportation costs represent a significant determinant doi:10.5937/ekoPolj2003683S

UDC 331.346.2:633.321/.324 of total operating costs, and therefore the selling price, which affects the competitiveness of products and the achieved business results. The aim of the paper is to point out the importance of respecting the financial effects of

Keywords:

transportation costs, management accounting, gross margin, agribusiness, competitiveness

JEL: M41, Q12 transport in the decision-making process of agribusiness management. The following methods have been used in the research: desk research, survey, direct costing method of calculation, sensitivity analysis and methods of descriptive statistics. Based on survey data conducted on farm of Central Serbia for the period 2016-2018, the paper analyzes the interdependence of transportation costs and gross margins in order to find out the factors that determine the decisions on production optimization as well as the business results of farm operations.
\end{abstract}

(C) 2020 EA. All rights reserved.

\section{Introduction}

Transport is an activity that influences value creation in a business cycle. As such it permeates numerous business functions starting from the procurement of inputs, through the internal transport of semi-finished products and finished products to the warehouse, up to the delivery of final products to customers. In addition to its impact on production activity, transport is an integral part of logistics and marketing, which directly affects the competitiveness of products and businesses.

1 Bojan Savić, Ph.D., Assistant Professor, University of Belgrade, Faculty of Agriculture, Nemanjina 6, Beograd-Zemun, Phone: +381 114413 211, E-mail: bsavic@agrif.bg.ac.rs, ORCID ID (https://orcid.org/0000-0002-3863-9630)

2 Mladen Petrović, Junior Researcher, Institute for Science Application in Agriculture, Bul. despota Stefana 68b, Phone: +38160525 11 95, E-mail: mpetrovic@ipn.bg.ac.rs, ORCID ID (https://orcid.org/0000-0002-4390-9711)

3 Zorica Vasiljević, Ph.D., Full Professor, University of Belgrade, Faculty of Agriculture, Nemanjina 6, Beograd-Zemun, Phone: +381 1144 13, E-mail: vazor@agrif.bg.ac.rs, ORCID ID (https://orcid.org/0000-0002-3076-3303) 
Transportation costs represent a significant determinant of total operating costs, and therefore the selling price, which affects the competitiveness of products and as such they affect the achieved business result. Namely, in the case of some agricultural crops, the purchasing price is extremely low, while on the other hand, the transportation costs due to their height are a key component of the total production costs. For the above reasons it is necessary to minimize the transportation costs through the optimization model. This contributes to the optimization of total operating costs.

The paper analyzes the relations between transportation costs and gross margin at the farm level for individual crop production lines. The aim of the paper is to point out the importance of respecting the financial effects of transport in the decision-making process of agribusiness management. Therefore the transportation problem is realized as an important element for improving the competitiveness of agricultural producers and positioning their products at the local and global market.

\section{Methods and Materials}

Several methodological procedures were used in the paper: the desk research method, survey method, direct costing method, sensitivity analysis and methods of descriptive statistics. The study is based on empirical data on production value, total variable costs, transportation costs and gross margins per ha of sown area for individual crop lines (wheat, maize, sunflower and soybeans). The survey was organized by The Institute for Science Application in Agriculture from Belgrade, conducted in Central Serbia in the period 2016-2018. The survey included 409 farms in 2016, 613 farms in 2017 and 370 farms in 2018.

\section{The role and importance of transport in agriculture and agribusiness}

Transport represents one of the primary activities in the value chain of an enterprise. Apart from the impact on the production activity (transportation of necessary inputs to the factory for the purpose of processing and internal movement of semi-finished goods into the warehouse), transport is integral to the function of logistics and marketing (delivery of finished products to distribution centers, retailers or customers) (Stepien, 2016). According to the results of the realized research by some authors, transport costs account for $1 / 3$ to $2 / 3$ of the total logistics costs, hence there is significant potential for cost reduction in this area (Stepien, 2016). This is all the more important, given the fact that transport costs over time have a tendency to grow due to rising fuel costs, increasing ecological taxes, increasing employee salaries in transport, population growth, and hence demand for fresh and frozen foods, etc.

Additionally, the progressive growth in transport costs is conditioned by internal factors such as inefficient use of means of transport, inadequate planning, organization, implementation and control of transport activities. It is also necessary to bear in mind the fact that the efficiency of transport activities has direct implications on the price competitiveness of the products and the market position of an enterprise. Due to the 
importance that in modern business conditions has for the long-term success of an enterprise, the issue of transport must be approached as an area of strategic importance.

Transport includes the physical transport of goods from the supply area, i.e. the location where the product is located in the stock, up to the place of demand or the location of the buyer (Lun et al., 2010). In other words, transport provides the transfer of goods from the place of production to the place of purchase / consumption. In this way, transport is a key component of the logistics process and as such is at the same time the biggest cost driver in the overall logistics chain.

Deciding on the transport domain is tangling the issue of transport and insurance. Transport activity assumes that a number of decisions have to be made, such as route selection, mode of transport, negotiation with the carrier (in cases where external production services are used), preparation of appropriate documentation etc. (Li et al., 2019; Djuričin et al., 2018; He \& Li, 2019).

The specifics of the organization of transport in agriculture and agribusiness are derived from the characteristics of inputs and final products and as such are defined by the conditions that are necessary for the preservation of their quantity and quality. Transport adds value to biological assets and agricultural products in a way to ensure their availability to the buyers/consumers. In other words, the value of agricultural products on a remote farm, where they are in fact inaccessible to most consumers and value in the immediate vicinity of markets is not the same. This is not only due to the deterioration of certain products that have to be transported in the short term to the cooling chain, but also due to the fact that the location of a particular asset is recognized in the Statement of Financial Position when measuring its fair value.

The three key components of the transport system include the infrastructure (ports or terminals), vehicles used for transportation, and an organization system that is necessary to ensure that vehicles and infrastructure are used effectively and efficiently (Lun et al., 2010; Fan et al., 2020).

An enterprise can carry out transport on its own, in conditions when it has the means of transport and trained personnel or by providing the transport services externally. Research has shown that leaving most of the distribution activities, including transport, to other specialized firms additionally increases the already high amount of these costs. Efforts to optimize transport costs cannot be reduced only to the endeavors in transferring transport costs to other participants in the supply chain, since in modern business conditions competitive battle does not run between individual enterprises, but between the entire supply chain. This further requires mutual cooperation and support from stakeholders, and they are seen as business partners who should work together to make optimum solutions for all participants, not as a rivalry and confrontation (Sekerez, 2007). 


\section{Strategic management of transportation costs in agribusiness}

Transportation costs include the depreciation of transport means, warehouses, material and energy use costs, salaries of employees engaged in transport operations, costs of external services such as transportation, loading, replacement, taxes and transport fees, and the like (Krakowiak-Bal et al., 2016). Energy costs participate with 40-50\%, maintenance costs of about $25 \%$, while the salaries of employees engaged in transport operations have a share of $20 \%$ of the total transportation costs.

Transportation costs can be classified in different ways. It is characteristic for the fixed costs that they are unchanged in total volume regardless of the volume of activity (Chivu et al., 2015). The fixed costs of transport include the cost of depreciation calculated using the application of time depreciation methods, then the costs of insurance and registration of transport means. Knowing fixed costs is important for determining the viability threshold, or for determining the minimum amount of activity (or revenue) that needs to be realized in order to make the company profitable. The variable transport costs include costs of fuel, lubricant and other means used for vehicle maintenance, toll costs, then salaries of employees who work on loading, unloading, transport, monitoring of transport, etc. Knowing the variable costs is important for deciding when there are more alternative solutions (Nielsen et al., 2015).

Considering the high share of transportation costs in overall logistics costs, it is necessary to devote considerable attention to improving the efficiency of transport activities, primarily through the process of analyzing past and current performances in order to review the current state of affairs and opportunities for improvement, thereby ensuring the efficient use of transport equipment and personnel. This assumes an analysis of whether available means of transportation correspond to real requirements and needs. In the case of oversize, i.e. the insufficient utilization of transportation means, the costs of unused capacity will be reported, which are treated as the expense of the period. Also, it is necessary to determine whether the loading space is effectively used, the time during which the goods are in transit, as these factors influence the number of deliveries that can be realized with certain transport equipment during the observed period, as well as the total transportation costs. Finding the best route should be based on an analysis of the network of road and river (maritime) routes, available lines of railways, air routes, in order to minimize distance, transport time and consequently incurred costs (Voortman, 2004).

For the purposes of perceiving the transportation cost drivers, some authors point to the possibility of applying more access (Bokor, 2010):

- The analytic hierarchy process (AHP) is used in cases where it is necessary to select one or more alternatives from the set of a multiple decision criterion analysis;

- Application of statistical techniques (regression and correlation) in the case when there are at disposal the time series on costs incurred activity and performance indicators over a number of years, in order to determine their connection, i.e. the cause-effect relationship; 
- Brainstorming meeting attended by managers of individual departments;

- Interviewing logistics department managers.

Based on these approaches it is possible to identify two groups of cost drivers resources (human resources, equipment, available vehicles, facilities, IT infrastructure) and activities (design, number of orders, machine hours, etc.). Also, cost drivers can be based on time, distance and volume: destination mix, source plants and warehouses, transportation routes, modes of transport, carriers, freight rate and the fuel surcharges. The passed kilometers, ton-kilometers, number of used stations and the like can be reported as performance indicators (Bokor, 2010). Furthermore, for each transport unit it is possible to identify the so-called carrying cost, i.e. the cost per $\mathrm{km}$ (based on distance) and cost per hour (related to the time duration of the transport), as well as the costs related to loading, unloading, and reloading (Gronland, 2011). The significance of the above identification of cost drivers is that each of them affects the amount of incurred costs, which at the same time represents the area for investigating the possibility of reducing costs (Betancor et al., 2005).

From the aspect of product or cost carrier, the costs of transport have the character of overheads, i.e. they are common to all products in an enterprise. Transportation costs in the production enterprise are covered through an internal account more accurately through the procedure for determining the service unit cost of the transport costs' place. Namely, the transport function has the role of an auxiliary cost place and, as such, provides services to other costs of the enterprise, both in production and nonproductive cost places. The unit cost per one hour of transport service includes the fixed and variable costs, as well as the primary and secondary costs.

The allocation of transport costs to cost carriers is therefore carried out using appropriate keys such as mileage, tons-kilometers, tons of stored products. One of the possible approaches to covering transport costs is the Transport costing method, which is based on the inclusion of costs for each vehicle on a daily basis. The number of cost units is calculated in transport by multiplying four factors: number of vehicles, traveled distance, number of day and transported quantity. As potential targets for calculating transport costs, the following can be identified (ISCI, 2014):

- control of operating and running cost and reduce of waste of fuel and other materials;

- compared cost of running own vehicles with other forms of transport;

- facilitates quotation of hiring rates to outside parties who ask for the transport service.

- determination of cost of idle vehicles and lost running time.

Optimization of logistics costs permeates the strategic, tactical and operational decision making levels (Škerlič et al., 2016; Savić et al., 2019). The strategy is important for transport issues, since it enables the identification of business opportunities, provides 
an objective insight into business problems, provides a framework for enhancing cooperation, minimizes the negative effects of risks and threats, improves the decisionmaking process and supports more efficient resource allocation. Developing a transport strategy involves the process of strategic analysis, strategy formulation, implementation and control of the strategy (Lun et al., 2010). Viewed from the perspective of transport, strategically important areas are the following: construction of distributive network, optimal distribution system planning, determination of optimal quantity of procurement, analysis of transport destinations, coordination of logistics network and distribution, inventory management, and more. The tactical decision-making level refers to the inventory management and product movement through the warehouse system (Elbert et al., 2020). Operational decisions in the domain of logistics relate to the acquisition of goods, the costs of their storage, as well as to the costs of missed sales due to the fact that it is not possible to meet the needs of customers (Salehi et al., 2017; Škerlič et al., 2016).

Factors that determine the amount of transport costs include total distribution capacity and total distance traveled. The capacity refers to the number and size of means of transport and has a direct impact on the costs of a fixed character. The total distance (expressed in kilometers) affects the number of vehicles that will be used for transport purposes and as such, this component of transport costs has a variable character (Abdallah, 2004). Furthermore, the factors that cause transport costs can be divided into factors that are related to the product itself (weight, size, value) and market-related factors (location of customers, whether they are located in the remote area or near the traffic port) (Voortman, 2004).

When solving a transport problem, it is important to have information about working time and the number of drivers in the observed enterprise. The information provided is used to evaluate the ability to carry out the transshipment of the required quantity of goods. Also, it is necessary to respect the frequency of trips, the speed at which a vehicle can cross a certain route, the capacity of the vehicle, the number of kilometers to be crossed, the time required to carry out basic logistics operations etc. (Xie et al., 2017; Abdallah, 2004).

Starting from the fact that transport has a significant share in the overall logistics costs, and therefore the total cost of doing business, profitable and sustainable business requires the management of transport costs. It is an effort to optimize them, i.e. transport costs should be reduced to a minimum, while there should be preserved the quality of goods that are the subject of transport. The following activities contribute to the optimization of transport costs (Voortman, 2004):

- determination of an effective transport route

- determination of an effective layout of the vehicle

- selection of the warehouse location. 
The time during which the goods are in transit affects the number of deliveries that can be realized with certain transport equipment during the observed period, as well as the total transport costs of all shipments. Finding an effective route should be monitored through a network of available roads, the railway lines, air routes, in order to minimize time, distance, costs and improve the quality of the service. Part of the effort to solve the transport problem relates to determining the distribution schedule for individual vehicles. The real constraints that need to be respected are as follows: each stop may have volume to be picked up as well as delivered, many transport means can be used and they can have different capacity constraints (size and cubic), the maximum transport time before the break is 8 hours, the stop can only be downloaded or delivered within a certain part of the day, the takeover can only take place after the delivery, the driver may have a break in a certain part of the day (Voortman, 2004).

The mentioned restrictions indicate the complexity of the transport problem and the necessary efforts to solve it. Namely, in addition to the location of the customer, there should be considered the distance, the time when the customer wants the product to be available, the costs of a particular mode of transport, the seasonal character of sales, whether the customers are in the country or abroad (Gonzales-Lopez et al., 2000). Comparison of the costs of individual alternatives can reveal some hidden transport costs. Finally, when it comes to site selection, it is necessary to consider the following factors: whether the company defines a market positioning strategy, when it seeks to be as close to customers as possible, or for a production positioning strategy, when it seeks to locate production facilities near sources of raw materials. Also, it is necessary to respect factors such as the development of transport infrastructure, the quality and capacity of transport facilities, the availability of skilled labor in a particular area, land costs and construction restrictions in a particular area (Voortman, 2004).

It is important to note that reducing transport costs cannot be an independent business goal. Namely, it is necessary to observe the connection between the costs of transport, revenues and profits arising from individual deliveries. By accepting a large number of small deliveries, the volume of sales increases, i.e. the level of revenues, but at the same time it does not guarantee an increase in profit. Namely, increasing the average transport costs can introduce an enterprise into the zone of loss, why many enterprises are discouraging the delivery of relatively small volume of products. Management accounting support for the transport cost reduction is reflected in generating of information as an integral part of supporting various cost management and costing systems such as Activity Based Costing/Management, Target Costing, Kaizen costing, etc. These concepts in practice are applied in an integrated manner with the aim of creating and maintaining a competitive advantage (Malinić et al., 2011; Shi et al., 2019).

Knowing the amount of transport costs is also important for the decision-making process whether to organize the transport by ourselves or to engage specialized organizations. In the case of the internal type of transport, the constraints represent relatively high costs of maintenance of means of transport and the fact that the company can only use road transport in the mentioned case. In favor of using external transport services, a http://ea.bg.ac.rs 
high degree of specialization and the possibility of choosing between different types of traffic (Božić et al., 2017).

\section{Results and Discussion}

Due to the fact that family farms in Serbia do not have a legal obligation to keep accounting records, the analytical calculation based on variable costs (direct costing method) is most often used in calculating and analyzing economic indicators of family farms. It is a much more convenient method than the analytical calculation of the full unit costs, since it does not require the availability of fixed costs' data for particular production lines, as well as data on overhead costs. Direct costing method is also used for determination of optimal volume and structure of production on farms (Gogić, 2014). This calculation assumes that the variable costs and direct costs of production are the same value.

The general formula for the direct costing calculation based on variable costs is as follows:

$$
\mathbf{P V}-\mathbf{V C}=\mathbf{G M}
$$

Whereas the meaning of indicators is as follows:

PV - Total production value in a particular production line;

$\mathrm{VC}$ - Total variable costs for particular production line;

GM - Gross margin (gross financial result).

The total production value (PV) is determined on the basis of the quantities produced on the farm in the particular line of production and their selling prices. In determining the $\mathrm{PV}$ of a particular production line, it is necessary to include both the value of the principal products and the value of the by-products obtained within the observed production line.

In this methodical procedure, the basis for calculating the variable costs are the quantities and prices of used raw materials in particular production. As a business result of operating a particular production line it is obtained the gross margin that represents the difference between the total production value and the total variable costs (Tasić, 2018). The gross margin per unit provides an opportunity for comparison of different production lines, as well as for selection of the most profitable production line in the given circumstances (Glenk et al., 2017). The aim of the direct costing calculation is to determine the contribution of the obtained products in covering the incurred costs, which primarily depends on the realized production values (Andrić, 1998).

Variable costs, among other things, include transportation costs. The fact that transport is a process that requires the involvement of labor, but also of transportation vehicles, storage capacities and other resources, suggests that the share of transport costs in total costs could be significant. For the purposes of direct costing calculation, it is necessary to have a record of transportation costs, which are mostly related to energy costs, which represent almost half of the total transportation costs in agricultural production (40-50\%). Therefore, transportation costs are an important parameter that must be taken into account 
not only because of the impact on the total costs of production and operating results, but also because of the environmental effects of transport activities and the possibility of additional costs arising on this basis (Daylan \& Ciliz, 2016; Savić et al., 2020).

Table 1 shows the number of farms surveyed in 2016-2018 and on which the gross margin data were collected for selected crop production lines. Considering the fact that maize and wheat represent the most represented crops in the agricultural production in the Republic of Serbia, the largest number of households surveyed refers to these two crops.

Table 1. Number of surveyed agricultural holdings

\begin{tabular}{|c|c|c|c|}
\hline Crop/year & $\mathbf{2 0 1 6}$ & $\mathbf{2 0 1 7}$ & $\mathbf{2 0 1 8 .}$ \\
\hline Maize & 121 & 286 & 201 \\
\hline Wheat & 177 & 209 & 117 \\
\hline Sunflower & 66 & 76 & 32 \\
\hline Soybean & 45 & 42 & 20 \\
\hline Summary & 409 & 613 & 370 \\
\hline
\end{tabular}

Source: Farm survey

Based on the gross margin data collected for the selected crops, Table 2 shows data relating to production value, total variable costs, gross margin, transportation costs and share of transportation costs in the total variable costs. Based on the presented data, it can be concluded that during the observed period there were no significant fluctuations in the total variable costs as well as in the share of transport costs in variable costs. On the other hand, all the surveyed crops recorded fluctuations in production value by particular years, which can be explained by the influence of weather conditions as well as fluctuations in purchasing prices of products.

Table 2. Economic indicators of selected crops' production

\begin{tabular}{|c|c|c|c|l|c|}
\hline Year & $\begin{array}{c}\text { Value of } \\
\text { production } \\
\text { (din/ha) }\end{array}$ & $\begin{array}{l}\text { Total variable } \\
\text { costs (din/ha) }\end{array}$ & $\begin{array}{c}\text { Gross } \\
\text { margin } \\
\text { (din/ha) }\end{array}$ & $\begin{array}{l}\text { Fuel costs } \\
\text { related to } \\
\text { transportation } \\
\text { (din/ha) }\end{array}$ & $\begin{array}{c}\text { Share of } \\
\text { transportation } \\
\text { costs in total } \\
\text { variable costs (\%) }\end{array}$ \\
\hline 2016 & $117,444.63$ & $57,743.12$ & $59,701.51$ & $1,539.18$ & 2.67 \\
\hline 2017 & $84,452.47$ & $59,466.44$ & $24,986.03$ & $1,541.50$ & 2.59 \\
\hline 2018 & $140,067.81$ & $63,240.86$ & $76,826.95$ & $1,900.52$ & 3.01 \\
\hline
\end{tabular}




\begin{tabular}{|c|c|c|c|c|c|c|}
\hline Year & $\begin{array}{c}\text { Value of } \\
\text { production } \\
\text { (din/ha) }\end{array}$ & $\begin{array}{c}\text { Total variable } \\
\text { costs (din/ha) }\end{array}$ & $\begin{array}{c}\text { Gross } \\
\text { margin } \\
\text { (din/ha) }\end{array}$ & $\begin{array}{l}\text { Fuel costs } \\
\text { related to } \\
\text { transportation } \\
\text { (din/ha) }\end{array}$ & $\begin{array}{c}\text { Share of } \\
\text { transportation } \\
\text { costs in total } \\
\text { variable costs (\%) }\end{array}$ \\
\hline 2016 & $98,737.51$ & $55,692.79$ & $43,044.72$ & $1,421.74$ & 2.55 \\
\hline 2017 & $95,538.09$ & $55,685.32$ & $39,852.77$ & $1,531.19$ & 2.75 \\
\hline 2018 & $85,610.09$ & $56,507.40$ & $29,102.69$ & $1,662.89$ & 2.94 \\
\hline \multicolumn{7}{|c|}{ Sunflower } \\
\hline 2016 & $116,034.85$ & $53,503.45$ & $62,531.40$ & $1,437.11$ & 2.69 \\
\hline 2017 & $100,850.00$ & $55,937.01$ & $44,912.99$ & $1,459.00$ & 2.61 \\
\hline 2018 & $88,353.13$ & $52,005.41$ & $36,347.72$ & $1,499.19$ & 2.88 \\
\hline 2016 & $136,644.44$ & $56,324.46$ & $80,319.98$ & $1,578.33$ & 2.80 \\
\hline 2017 & $85,723.81$ & $57,261.61$ & $28,462.20$ & $1,656.17$ & 2.89 \\
\hline 2018 & $130,540.00$ & $63,851.25$ & $66,688.75$ & $1,862.22$ & \\
\hline
\end{tabular}

Source: Farm survey

Figure 1. Amounts of total variable costs and gross margin in production value

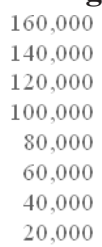
140,000
120,000
100,000
80,000
60,000
40,000
20,000

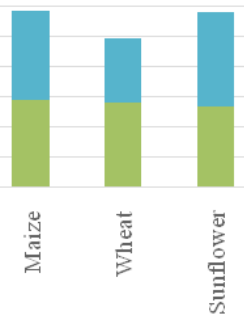

2016

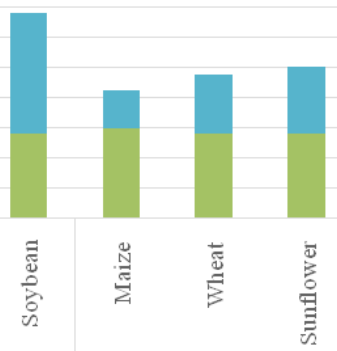

2017

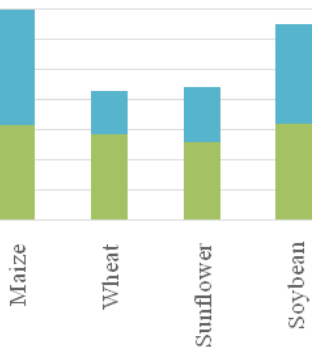

2018

- Total variable costs $\quad$ Gross margin

Source: Authors' presentation based on the farm survey data

Figure 1 shows the relationship between total variable costs and gross margin. Since production value has a pronounced volatility, as already has been pointed out, while variable costs tend to have a slight upward trend, the changes in gross margin can be explained primarily by changes in production value. 
In the case of maize production it can be observed that the gross margin in 2016 was $59,701.51 \mathrm{din} / \mathrm{ha}$, while this amount in 2017 was $24,986.03 \mathrm{din} / \mathrm{ha}$, and in 2018 it was $76,826.95 \mathrm{din} / \mathrm{ha}$. In the case of wheat, the gross margin tended to decline throughout the observation period, from $43,044.72 \mathrm{din} /$ ha in 2016 , to $39,852.77 \mathrm{din} /$ ha in 2017 , up to $29,102.69 \mathrm{din} /$ ha in 2018. Sunflower had the largest gross margin in $2016(62,531.40$ $\mathrm{din} / \mathrm{ha}$ ), in 2017 that amount was 44,912.99 din/ha and in 2018 it was 36,347.72 din/ha. Soybean also recorded the highest gross margin in $2016(80,319.98 \mathrm{din} / \mathrm{ha})$, in 2017 it was $28,462.20 \mathrm{din} / \mathrm{ha}$ and in 2018 it was $66,688.75 \mathrm{din} / \mathrm{ha}$.

Figure 2. Amounts of diesel for transportation cost in total variable costs of production

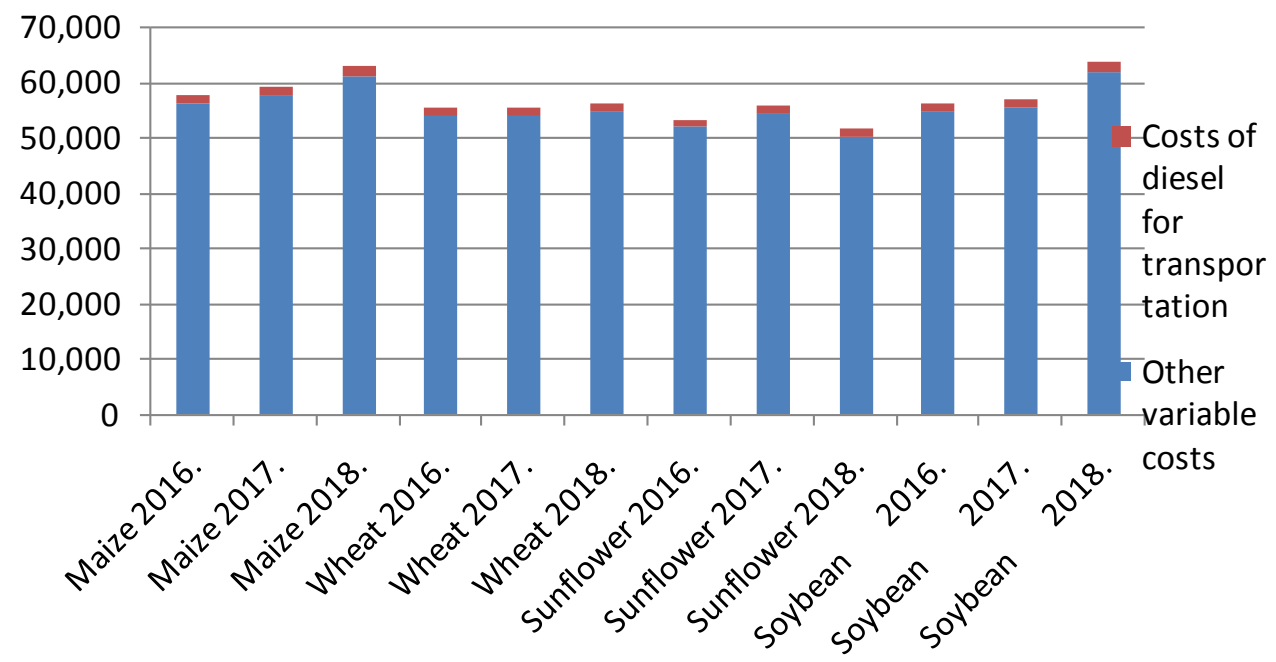

Source: Authors' presentation based on the farm survey data

Figure 2 shows the share of transportation costs related to the consumption of diesel fuel for the sowing and harvesting activities of particular crops in the total variable costs. This share did not vary significantly over the observed period and ranged from $2.55 \%$ to $3.01 \%$ of the total variable costs.

Based on the analyzed data it can be observed that the purchasing prices for maize and wheat were relatively stable in analyzed period, while the oscillation of the purchasing prices was expressed for sunflower and soybeans. The price range for sunflower was 26.95-30.68 din $/ \mathrm{kg}$, while the price of soybean ranged from 35.39-45.02 din $/ \mathrm{kg}$. It can be noticed in the case of sunflower that the purchasing prices have been reduced from year to year, while the transportation costs and total variable costs have been increased. These trends could explain the declining trend of gross margin over the analyzed period in the case of sunflower production.

Given the drastic decrease in the price of soybeans in 2018 (35.39 din $/ \mathrm{kg}$ ) compared to 2017 (45.02 din/ $\mathrm{kg}$ ), it is presented in the paper the sensitivity analysis of the gross margin in soybean production line, in order to look at the impact of the negative price http://ea.bg.ac.rs 
trend on the value of production as well as on the gross margin. The fact that in the observed period there was a tendency of increase in the price of diesel, both in absolute amount (from $136.50 \mathrm{din} /$ lit in 2016 to $160.85 \mathrm{din} /$ lit in 2018) and relatively as a share of variable costs, it has conditioned the need to consider the impact of diesel fuel costs used for transportation should be selected as the second parameter in the sensitivity analysis.

Table 3 there are given different scenarios resulting from a combination of changes (increase or decrease) in diesel costs for transport and production values, as well as the resulting gross margin amounts.

Table 3. Sensitivity analysis of gross margin in the case of soybean production

\begin{tabular}{|c|c|c|c|c|c|c|}
\hline & & \multicolumn{5}{|c|}{ Fuel costs related to transportation (din/ha) } \\
\hline & & $-20 \%$ & $-10 \%$ & Expected & $+10 \%$ & $+20 \%$ \\
\hline $\begin{array}{c}\text { Production } \\
\text { values (din/ha) }\end{array}$ & $\mathbf{1 , 4 8 9 . 7 8}$ & $\mathbf{1 , 6 7 6 . 0 0}$ & $\mathbf{1 , 8 6 2 . 2 2}$ & $\mathbf{2 , 0 4 8 . 4 4}$ & $\mathbf{2 , 2 3 4 . 6 6}$ \\
\hline$-20 \%$ & $\mathbf{1 0 4 , 4 3 2 . 0 0}$ & $40,953.19$ & $40,766.97$ & $40,580.75$ & $40,394.53$ & $40,208.31$ \\
\hline$-10 \%$ & $\mathbf{1 1 7 , 4 8 6 . 0 0}$ & $54,007.19$ & $53,820.97$ & $53,634.75$ & $53,448.53$ & $53,262.31$ \\
\hline Expected & $\mathbf{1 3 0 , 5 4 0 . 0 0}$ & $67,061.19$ & $66,874.97$ & $\mathbf{6 6 , 6 8 8 . 7 5}$ & $66,502.53$ & $66,316.31$ \\
\hline$+10 \%$ & $\mathbf{1 4 3 , 5 9 4 . 0 0}$ & $80,115.19$ & $79,928.97$ & $79,742.75$ & $79,556.53$ & $79,370.31$ \\
\hline$+20 \%$ & $\mathbf{1 5 6 , 6 4 8 . 0 0}$ & $93,169.19$ & $92,982.97$ & $92,796.75$ & $92,610.53$ & $92,424.31$ \\
\hline
\end{tabular}

Source: Authors' calculation based on the farm survey data

Based on the analysis, it can be concluded that the gross margin in soybean production is the lowest when the costs of diesel for transportation have been increased and at the same time the value of production has been reduced. The highest gross margin should be achieved in the case of reduced diesel costs for transportation together with simultaneous production value increase. The shown changes in production value can be explained by the dynamics of the yield per ha, as well as the volatility of purchasing prices. When it comes to the costs of diesel for transportation, they are determined by the market price of fuel, but also by the amount of fuel subsidies that the state gives to the farmers.

\section{Conclusion}

In addition to the risks arising from the specificity of agricultural production and climate changes, agricultural producers are increasingly exposed to the risks of market nature, above all the risk of changes in the prices of finished agricultural products and raw materials.

If the negative trend in the purchasing prices of cereals and industrial plants continues in several consecutive years, it could be raised the question concerning the economic effectiveness of production in the case of some crops. This will undoubtedly require changes in the production structure, i.e. making decisions on optimization of production 
structure. In addition, given the fact that the purchasing prices of crops and the price of diesel fuel are determined by factors beyond the control of farmers, the farmers should do their best to adjust their operations by managing risk connected with the price changes of agricultural products and raw materials.

When it comes to generating revenue, risk can be mitigated, among other things, by signing the commodity futures contracts, while when it comes to the costs, the farmers need to assess whether they can fit into costs that allow the positive business result. In other words, given the volatility of price, the farmers should start from the lowest purchasing price of their products in the previous period and simultaneously project the movement of certain cost categories, in order to assess the possibility of profitable business within the stated frameworks.

When it comes to transportation costs, it is important to note that reducing transport costs cannot be an independent business goal. Namely, it is necessary to observe the connection between the costs of transportation, variable costs and gross margins. Management accounting support for the transportation cost reduction is reflected in generating of information as an integral part of supporting various cost management and costing systems.

\section{Acknowledgements}

The paper is a result of the researching project financed by The Ministry of Education, Science and Technological Development of the Republic of Serbia No. 451-0368/2020-14/200116.

\section{Conflict of interests}

The authors declare no conflict of interest.

\section{References}

1. Abdallah, H. (2004). Guidelines for Assessing Costs in a Logistics System: An Example of Transport Cost Analysis, Arlington, John Snow, Inc/DELIVER.

2. Andrić, J. (1998). Costs and Calculations in Agricultural production, Savremena administracija, Beograd.

3. Betancor, O., Carmona, M., Macario, R., \& Nash, C. (2005). Operating cost, In: Nash, C., \& Matthews, B. (eds.), Measuring the Marginal Social Cost of Transport, Elsevier, 85-125.

4. Bokor, Z. (2010). Cost drivers in transport and logistic. Transportation Engineering, 38(1), 13-17. doi: https://doi.org/10.3311/pp.tr.2010-1.03

5. Božić, V., Aćimović, S., \& Miljušković, V. (2017). The Economics of Traffic, Ekonomski fakultet, Beograd. 
6. Chivu, L., Ciutacu, C., \& Georgescu, L. (2015). Household income in Romania. A challenge to economic and social cohesion. Procedia Economics and Finance, 22, 398-401. doi: https://doi.org/10.1016/S2212-5671(15)00310-X

7. Daylan, B., \& Ciliz, N. (2016). Life cycle assessment and environmental life cycle costing analysis of lignocellulosic bioethanol as an alternative transportation fuel. Renewable Energy, 89, 578-587. doi: https://doi.org/10.1016/j.renene.2015.11.059

8. Djuričin, D., Kaličanin, Đ., Lončar, D., \& Vuksanović-Herceg, I. (2018). Management and strategy, Ekonomski fakultet, Beograd.

9. Elbert, R., Muller, J., \& Rentschler, J. (2020). Tactical network planning and design in multimodal transportation - A systemic literature review. Research in Transportation Business \& Management, 35, 1-21. doi: https://doi.org/10.1016/j. rtbm.2020.100462

10. Fan, T., Pan, Q., Pan, F., Zhou, W., \& Chen, J. (2020). Intelligent logistic integration of internal and external transportation with separation mode. Logistic and Transportation Review, 133, 1-16. doi: https://doi.org/10.1016/j.tre.2019.10.011

11. Gogić, P. (2014). Theory of costs with calculations in production and processing of agricultural products, Poljoprivredni fakultet, Beograd.

12. Gonzales-Lopez, E., Rodriguez-Fernandez, M.A., \& Mendana-Cuervo, C. (2000). The Logistic Decision Making in Management Accounting with Genetic Algoritms and Fuzzy Sets. Mathware and Computing, 7, 229-241.

13. Glenk, K., Shrestha, S., Topp, C., Sanchez, B., Iglesias, A., Dibari, C., \& Merante, P. (2017). A farm level approach to explore farm gross margin effects of soil organic carbon management. Agricultural Systems, 151, 33-46. doi: https://doi. org/10.1016/j.agsy.2016.11.002

14. Gronland, S. E. (2011). Cost models for transportation and logistics, Institute of transport economics, Oslo.

15. He, P., \& Li, J. (2019). The two-echelon multi-trip vehicle routing problem with dynamic satellites for crop harvesting and transportation. Applied Soft Computing Journal, 77, 387-398. doi: https://doi.org/10.1016/j.asoc.2019.01.040

16. Krakowiak-Bal, A., \& Sokora, J. (2016). The Logistic Cost Analysis in Agribusiness - Case Study of Food Sector Company. Infrastruktura i ekologija terenow eiejskich, 4(3), 1535-1545. doi: http://dx.medra.org/10.14597/infraeco.2016.4.3.114

17. Li, J., Qin, H., Shen, H., \& Tsui, K. (2019). The unilateral transportation problem. Logistic and Transportation Review, 132, 1-29. doi: https://doi.org/10.1016/j. tre.2019.10.004

18. Lun, Y., Lai, K., \& Cheng, T. (2010). Shipping and Logistics Management, Springer Verlag London Limited.

19. Malinić, S., \& Janković, M. (2011). Integrated cost management in distribution chain - strategic approach and management accounting information supports, Računovodstvo, 55(7-8), 11-24. 
20. Nielsen, L., Mitchell, F., \& Norreklit, H. (2015). Management accounting and decision making: Two case studies of outsourcing. Acounting Forum, 39, 64-82. doi: https://doi.org/10.1016/j.accfor.2014.10.005

21. Salehi, M., Jalalian, M., \& Vali Siar, M. (2017). Green transportation scheduling with speed control: trade-off between total transportation cost and carbon emission. Computers \& Industrial Engineering, 113, 392-404. doi: https://doi.org/10.1016/j. cie.2017.09.020

22. Savić, B., Milojević, I., \& Petrović, V. (2019). Cost optimization in agribusiness based on life cycle costing. Economics of agriculture, 3(66), 823 - 834. doi: https:// doi.org/10.5937/ekoPolj1903823S

23. Savić, B., Vasiljević, Z., \& Milojević, I. (2020). Costing system as an instrument for enhancing environmental performance of entities in agribusiness. Journal of Business Economics and Management, 3-4(68), 294-302. doi: https://doi. org/10.5937/EKOPRE2004294S

24. Sekerez, V. (2007). Concept of Cost Management through Supply Chain, In: Chalenges of Business and Financial Reporting for the Purpose of Enterprise and Bank management, XXXVIII Simpozijum Saveza računovođa i revizora Srbije, Zlatibor, 24-26. maj, 65-80. .

25. Shi, Y., Arthanari, T., Liu, X., \& Yang, B. (2019). Sustainable transportation management: Integrated modeling and support. Journal of Cleaner Production, 212, 1381-1395. doi: https://doi.org/10.1016/j.jclepro.2018.11.209

26. Stepien, M., Legowik-Swiacik, S., Skibinska, W., \& Turek, I. (2016). Identification and Measurement of Logistic Cost Parameters in the Company. Transportation Research Procedia, 16, 490-497.

27. Škerlič, S., Muha, R., \& Logožar, K.A. (2016). Decision-Making Model for Controling Logistic Costs. Tehnički vjesnik, 23(1), 145-156. doi: https://doi. org/10.17559/TV-20141015121023

28. The Institute of Company Secretaries of India, (2014). Cost and Management Accounting, M.P. Printers, New Delhi.

29. Tasić, J. (2018). Geographical and economic performance of organic agriculture and its impact on the gastronomy tourism in Serbia. Oditor - Časopis za menadžment, finansije i pravo, 4(1), 38-51. doi: https://doi.org/10.5937/Oditor1801038T

30. Voortman, C. (2004). Global Logistics management, Juta \& Co Ltd, Cape Town.

31. Xie, F., Butt, M., Li, Z., \& Zhu, L. (2017). An upper bound on the minimal total cost of the transportation problem with varying demands and supplies. Omega, 68, 105-118. doi: https://doi.org/10.1016/j.omega.2016.06.007 